\title{
Nowy argument z projektu *
}

Niemal w tym samym momencie, gdy naukowcy uznali, że już wiedzą, jak naturalne procesy wyjaśniają uporządkowanie Wszechświata, odkryli, iż w przyrodzie istnieje bardzo szczególny rodzaj złożoności nazywany informacją. Doświadczenie nauczyło ich, że za informacją zawsze musi kryć się inteligencja. Za sprawą odkryć dokonanych w dwudziestym wieku badacze uświadamiają sobie, że posłużenie się tymi samymi metodami, za pomocą których identyfikowano dotychczas przyczyny naturalne (rozumowanie na podstawie doświadczenia), wskazuje na jakąś przyczynę inteligentną. Oznacza to jednak sprzeniewierzenie się założeniom przyjętym przez uczonych żyjących w dziewiętnastym wieku. Czy dwudziestowieczni naukowcy mogą porzucić te dziewiętnastowieczne założenia, zanim wkroczą w wiek dwudziesty pierwszy?

Filozofowie i teologowie od dawien dawna dowodzili istnienia Boga na podstawie argumentu z projektu. W myśl klasycznej wersji tego argumentu za obserwowane w świecie przejawy uporządkowania czy wzorce odpowiada przyczyna inteligentna zwana Bogiem. W dziewiętnastym wieku archidiakon William Paley dopracował go i nadał mu najbardziej elokwentną i przekonującą formę. Porównywał on uporządkowanie, jakim cechują się ludzkie artefakty, z uporządkowaniem

*Charles Thaxton, „A New Design Argument”, Cosmic Pursuit, 1 March 1998, http:// www.discovery.org/a/137 (19.06.2010). Z języka angielskiego za zgodą Autora przełożyła Izabela JANus. Recenzent: Józef Zon, Katedra Biologii Teoretycznej Katolickiego Uniwersytetu Lubelskiego. Wszystkie przypisy pochodzą od thumaczki. 
obserwowanym w przypadku istot żywych. Skoro za artefakty odpowiada ludzka inteligencja, rozumował Paley, to istoty żywe musiały powstać dzięki jakiejś podobnej inteligentnej sile, ale przewyższającej ludzką.

Argument ten przekonywał niegdyś wielu ludzi, lecz obecnie do większości wykształconych osób już nie przemawia. Wiara w projekt osłabła wraz z akceptacją naukowego obrazu świata. Trzysta lat po ukazaniu się Principiów Newtona, w których przedstawił on mechanistyczne ujęcie funkcjonowania kosmosu, oficjalny i szeroko akceptowany pogląd naukowy głosi, że na przebieg zdarzeń we Wszechświecie nie wpływa żaden inteligentny czynnik. Większość wykształconych ludzi uważa obecnie, że idea projektu w przyrodzie jest anachronizmem, zaś każdego, kto przyjmuje słuszność argumentu z projektu, należy uznać za niedoinformowanego.

Ponad wiek po Darwinie w kulturze ugruntowało się przekonanie, że ludzie i wszystkie istoty żywe są wytworem sił fizycznych działających na Ziemi i w całym kosmosie. Zgodnie $\mathrm{z}$ dominującym poglądem naukowym powstanie istot żywych nie było przez nikogo zaplanowane czy zamierzone. W opinii Richarda Dawkinsa z Oxfordu są one tylko „obiektami złożonymi, tworzącymi wrażenie celowego zamysłu". ${ }^{1}$

Do odrzucenia idei projektu w naszej kulturze przyczyniła się dziewiętnastowieczna nauka, ale największe naukowe odkrycia dwudziestego wieku dostarczają podstaw dla gruntownej zmiany poglądów na tę ideę. Odkryć tych dokonywano jednak szybciej niż kultura mogła je przyswoić. W ramach kultury, jako całości, tylko w niewielkim stopniu uświadamiano sobie głębsze implikacje takich wspaniałych osiągnięć jak rewolucyjna Einsteinowska teoria względności, mechanika kwantowa, odkrycie struktury DNA i zrozumienie procesu dziedzicze-

\footnotetext{
${ }^{1}$ Richard DawkINS, Ślepy zegarmistrz czyli, jak ewolucja dowodzi, że świat nie zostal zaplanowany, przeł. Antoni Hoffman, Biblioteka Myśli Współczesnej, Państwowy Instytut Wydawniczy, Warszawa 1994, s. 21.
} 
nia oraz związanego z nimi postępu w zakresie medycyny molekularnej, a także wielka rewolucja komputerowa, która zaowocowała powstaniem Internetu i cyberprzestrzeni.

Dziś wybitni naukowcy znów zaczynają nabierać przychylnego stosunku do idei projektu we Wszechświecie. W 1995 roku fizyk kwantowy Paul Davies otrzymał Nagrodę Templetona za Krzewienie Religii. W przemówieniu wygłoszonym podczas ceremonii wręczenia nagrody, którego treść opublikowano na łamach First Things, entuzjastycznie wypowiadał się on na temat projektu we Wszechświecie. Zauważmy, że Davies nie jest jedynym naukowcem odnoszącym się do idei projektu $\mathrm{z}$ tak dużą życzliwością. $\mathrm{O}$ zadziwiających cechach Wszechświata, które przywodzą na myśl projekt, można przeczytać w wielu książkach: The Grand Design [Wielki projekt], Bóg i nowa fizyka, Disturbing the Universe [Zaburzając Wszechświat], The Anthropic Cosmological Principle [Kosmologiczna zasada antropiczna], The Symbiotic Universe [Symbiotyczny Wszechświat], Perfect Symmetry [Doskonała symetria] czy The Cosmic Code [Kosmiczny kod]. Temat projektu we Wszechświecie ewidentnie zyskuje rangę coraz bardziej wiarygodnego przedsięwzięcia.

Astronomowie i fizycy końca dwudziestego wieku posługują się terminem ,projekt”, ale większość z nich, jak Davies, ma na myśli jedynie projekt pozorny i uważa, że różne zaobserwowane we Wszechświecie zadziwiające wzorce są rezultatem działania praw przyrody. W najlepszym razie uznać można, że nie rozstrzygają oni, czy prawa przyrody są dziełem projektanta. Często jednak nietrudno odnieść wrażenie, że odrzucają tę możliwość.

Przełomowe odkrycia $\mathrm{w}$ matematyce $\mathrm{i}$ biologii są równie interesujące i ekscytujące, jak te w fizyce i astronomii. Postaram się wykazać, że one także przemawiają za istnieniem projektu, którego twórcą jest inteligentny projektant, aczkolwiek niewielu naukowców ma odwagę wyciągnąć taki wniosek z wyników swoich badań.

Nowy argument z projektu, sformułowany na gruncie biologicznym i matematycznym, nie jest tak dobrze znany, jak ten wywodzący 
się z astronomii czy fizyki, ale może być ważniejszy. Jeśli uda się wykazać, że ten argument jest słuszny, to za jego pomocą można uzyskać podstawę do rozjaśnienia obrazu uzyskanego na podstawie danych astronomii i fizyki. Właśnie ten nowy argument $\mathrm{z}$ projektu będzie przedmiotem niniejszego artykułu.

\section{Metoda wnioskowania abdukcyjnego}

Rozumowanie, którego podstawę stanowi zgromadzone dotychczas doświadczenie, jak również przyporządkowywanie określonych przyczyn danym skutkom, to od dawna już stosowana, udoskonalana i uznana naukowa metoda wnioskowania przyczynowego. W nauce pojawiła się ona za sprawą rewolucji naukowej, której kulminacją była wielka Newtonowska synteza z siedemnastego wieku. Gdy w kulturze zachodniej rozwinęła się nowoczesna nauka o charakterze eksperymentalnym, wiedzę o zjawiskach przyrodniczych zaczęto zdobywać drogą doświadczenia zmysłowego. Kierując się doświadczeniem, naukowcy nauczyli się wnioskować o przyczynach na podstawie skutków, to jest rozumować wstecz — od cech skutków do przyczyny.

Przyczyna - wszystko jedno: naturalna czy inteligentna - to konieczny i wystarczający warunek zajścia danego zdarzenia. Jak wyraził się Dawid Hume, który przeprowadził formalną analizę tego podejścia: ,po przyczynach, które wydają się podobnymi, spodziewamy się podobnych skutków". ${ }^{2} \mathrm{~W}$ tej samej książce stwierdził też, że ,ta sama zasada pozostaje ważną bez względu na to, czy domniemana przyczyna jest martwą, nieświadomą materią, czy też rozumną, inteligentną istotą". ${ }^{3}$

Metody wnioskowania, których zazwyczaj uczymy się w szkole, to dedukcja, czyli wnioskowanie od ogółu do szczegółu, oraz indukcja

\footnotetext{
${ }^{2}$ Dawid Hume, Badania dotyczące rozumu ludzkiego, przeł. Jan Łukasiewicz i Kazimierz Twardowski, Tłumaczenia Klasyków Filozofii, Polska Akademia Umiejętności, Kraków 1947, s. 37.

${ }^{3}$ Hume, Badania dotyczące rozumu ludzkiego..., s. 134.
} 
— wnioskowanie od szczegółu do ogółu. Jednak zawsze istniała jeszcze jedna metoda wnioskowania, która ścisłego opisu i formalnej analizy doczekała się dopiero w latach siedemdziesiątych dziewiętnastego wieku. Jest nią abdukcja, to znaczy wnioskowanie na podstawie doświadczenia. Metoda wnioskowania abdukcyjnego szczególnie istotną rolę pełni w naukach historycznych, w których rozumuje się wstecz od zjawisk do przyczyn.

Rozważmy kilka przykładów. Spacerując wzdłuż plaży obmywanej przez fale morskie, zauważamy na piasku faliste wzory. Za pierwszym razem mogą się one wydawać tajemnicze, ale kiedy takie doświadczenie się powtarza, zaczynamy takie wzory kojarzyć z działaniem morskich fal. Tak bardzo przyzwyczajamy się do przypisywania tej przyczyny tego typu skutkom, że widząc fotografie podobnych falistych wzorów w osadach datowanych przez geologów na trzy miliardy lat, również wnioskujemy, że ich naturalną przyczyną jest woda.

Także głębokie kanały czy rowy na powierzchni Marsa są tak podobne do tego, co z doświadczenia znamy jako skutek oddziaływania płynącej wody, że za ich naturalną przyczynę uznajemy właśnie wodę, mimo iż obecnie związek ten na Marsie nie występuje. To właśnie na tej zasadzie naukowcy z NASA orzekli, że w przeszłości na Marsie musiała występować woda.

Z kolei, gdybyśmy wędrowali w Black Hills w Południowej Dakocie i dotarli do granitowych klifów przypominających twarze czterech prezydentów Stanów Zjednoczonych, momentalnie stwierdzilibyśmy, że Mount Rushmore jest dziełem rzemieślników, a nie wytworem wiatru i erozji. Rezerwuar zgromadzonego przez nas doświadczenia pozwala nam określać typy obserwowanych skutków i odróżniać przyczyny naturalne od inteligentnych. A co byłoby, gdybyśmy podążyli dalej i zobaczyli skałę, na której widnieje napis „Jaś kocha Małgosię”? I tym razem doświadczenie podpowiadałoby nam, że jest to czyjś (zapewne Jasia lub Małgosi) wyraz uczuć. Dzięki temu, że potrafimy rozróżniać przyczyny, nie uznalibyśmy tego napisu za dzieło procesów erozyjnych. 
To właśnie za sprawą tej zdolności antropologowie zmienili w końcu zdanie na temat eolitów. Eolity to odłupane krzemienie, które przez wiele lat uważano za wytwór wczesnego człowieka. Później odkryto, że takie odłamki i rysy na skałach mogą powstawać w wyniku obtłukiwania się krzemieni w strumieniu. W tym wypadku określonemu skutkowi przypisano inną przyczynę niż dotychczas, ponieważ zdobyto dodatkowe doświadczenie.

Metoda abdukcyjna umożliwia badanie zjawisk $\mathrm{z}$ otwartym umysłem, czyli z gotowością do uwzględnienia zarówno przyczyn naturalnych, jak inteligentnych. W tym ujęciu przyczynę określa się na podstawie cech skutku. By zilustrować tę metodę, przypuśćmy, że jesteśmy detektywami prowadzącymi dochodzenie w sprawie czyjejś śmierci. Czy była to śmierć z przyczyn naturalnych (wypadek), czy też śmierć „zaprojektowana” (morderstwo lub samobójstwo)? Nie znamy odpowiedzi z góry. Rozwiązanie tej sprawy wymaga badań. Gdybyśmy już przed rozpoczęciem dochodzenia ogłosili, że śmierć była przypadkowa (naturalna), ktoś słusznie mógłby postawić zarzut, że bezpodstawnie ograniczyliśmy zakres możliwych przyczyn.

Skoro jednym z głównych celów dochodzenia kryminalnego jest określenie, czy za czyjąś śmierć odpowiada przyczyna inteligentna (a więc, czy było to morderstwo lub samobójstwo), czy też naturalna, to potrzebujemy metody dopuszczającej każdą możliwość. Abdukcyjna metoda rozumowania wstecz (od skutków do przyczyny) umożliwia ocenę różnych hipotez, mówiących tak o naturalnych, jak o inteligentnych przyczynach, oraz eliminację tych, którym przeczy doświadczenie. Ta otwartość na pełne spektrum scenariuszy - mogących objąć nie tylko przyczyny naturalne, ale też inteligentne — daje poczucie pewności, że za pomocą wnioskowania abdukcyjnego jesteśmy w stanie wskazać najlepsze wyjaśnienie.

Mimo to niektórzy (w tym większość naukowców) sugerują, że nauka nie może rozważać przyczyn inteligentnych. Takie rozumienie nauki jest jednak ewidentnie błędne, bowiem we współczesnej nauce wnioskowanie abdukcyjne mocno się już zakorzeniło. Uczeni z NASA 
rutynowo stosują retrospektywne rozumowanie przyczynowe, kiedy w ramach programu SETI (Search for Extra-Terrestrial Intelligence) poszukują w przestrzeni kosmicznej oznak inteligencji. Gdyby sygnały wychwycone z kosmosu przenosiły sztuczne drgania elektromagnetyczne, w których zakodowano pierwszy tysiąc cyfr liczby przestępnej $3,14159 \ldots$, badacze uznaliby to za coś tak mało prawdopodobnego, że wszyscy zgodziliby się, iż pochodzą one od inteligentnych istot. Gdyby naukowcy natrafili kiedyś na sygnały radiowe wyróżniające się na tle szumu kosmicznego i noszące oznaki inteligencji, z pewnością moglibyśmy spodziewać się triumfalnego obwieszczenia tego z Waszyngtonu.

Własny program przeszukiwania przestrzeni kosmicznej — „Billion Channel Extraterrestrial Assay" (BETA) — rozpoczęło także Planetary Society. W jego ramach wykorzystuje się jeden z największych na świecie odbiorników — radioteleskop o średnicy 26 metrów, który znajduje się w Harvard University w stanie Massachusetts. Celem programu jest odbiór inteligentnie zaprojektowanych wiadomości, które mogłaby wysyłać jakaś zaawansowana cywilizacja pozaziemska. Widać więc, że taka działalność mieści się w granicach prawowitej nauki. Śmiało możemy zatem zapomnieć o tezie, że współczesna nauka z zasady wyklucza możliwość powoływania się na przyczyny inteligentne.

\section{Jak przyczyny inteligentne zniknęly z nauk przyrodniczych}

Mimo że przyczyny inteligentne to pełnoprawny element programu poszukiwania istot pozaziemskich (a także archeologii, antropologii i medycyny sądowej), w naukach przyrodniczych nikt już się na takie przyczyny nie powołuje. Spróbujmy zrozumieć, dlaczego tak się stało, w naszych rozważaniach jest to bowiem kwestia o kluczowym znaczeniu.

Przez większą część historii Zachodu wierzono w istnienie projektu. Naukowcy z góry przyjmowali, że świat jest uporządkowany i zaprojektowany. Według Whiteheada nie były to ,jawnie głoszone przekonania nielicznych jednostek”, a raczej „wpływ, jaki na umysły euro- 
pejskie wywarła niepodważalna wiara całych stuleci”. Nie były to więc ,jawnie głoszone przekonania, lecz [...] instynktowny sposób myślenia". ${ }^{4}$ Jednym z celów poszukiwań naukowych, prowadzonych z perspektywy wiary, było odkrywanie praw opisujących obserwowane w świecie prawidłowości i porządkujących to, co z pozoru wydaje się chaotyczne. Naukowcy oraz członkowie szerzej pojmowanej kultury milcząco przyjmowali przekonanie, że za uporządkowaniem kryje się wielka, nadająca porządek inteligencja, czyli Bóg.

Europejczycy wierzyli w to tak głęboko, że tylko nieliczni (i to nawet dziewiętnastowieczni) naukowcy nie zgadzali się z Izaakiem Newtonem, iż „Ten najpiękniejszy system słońca, planet i komet mógł powstać jedynie $\mathrm{z}$ zamiaru i władztwa inteligentnej i potężnej Istoty". 5

Ponieważ w kulturze zachodniej panowało przeświadczenie, że Wszechświat (w tym Ziemia i życie) został stworzony i zaprojektowany, już od samego początku istnienia siedemnastowiecznej nauki aż po czasy Darwina powszechnie uważano, iż nauka nie zajmuje się kwestią pochodzenia. Zapewne ludzie zadawali sobie pytanie: „dlaczego mielibyśmy naukowo dowodzić czegoś, o czym już wiemy?”. Świat został stworzony i zaprojektowany, a nauka szuka praw opisujących obserwowane w świecie prawidłowości. Autor artykułu, który opublikowano na łamach London Times w czasach burzliwego sporu wokół teorii Darwina, wyraził dominujący w ówczesnej kulturze i podzielany przez większość naukowców pogląd, pisząc: „od ludzi Nauki oczekujemy raczej prowadzenia obserwacji, nie zaś zdawania się na wyobraźnię".

Niepostrzeżenie wyłonił się jednak nurt naturalizmu naukowego, któremu odpowiadał inny rytm wybijany przez marszowy werbel. W kulturze oraz pośród większości naukowców panował tak wielki

\footnotetext{
${ }^{4}$ Alfred North WhiteheAd, Nauka i świat nowożytny, przeł. Maciej Kozłowski i Marek Pieńkowski, Wydawnictwo ZNAK, Kraków 1987, s. 35.

${ }^{5}$ Isaac Newton, Mathematical Principles of Natural Philosophy, ed. R.M. Hutchins, Great Books of the Western World, Chicago 1952, s. 369.
} 
zachwyt nad licznymi prawidłowościami przyrody i faktami potwierdzającymi ówczesne podstawowe przekonania, że prawie wszystkim umknął fakt, że w ramach naturalizmu naukowego prawidłowości przyrodnicze zaczęły stanowić podstawę dla wniosku o istnieniu absolutnych praw przyrody, których nawet Bóg (o ile istnieje) musi przestrzegać. Naturaliści zastąpili Boga przyrodą. Religijna ortodoksja nie przestała istnieć, ale w kręgach intelektualnych dokonała się umysłowa rewolucja - nastąpił radykalny zwrot od teizmu ku naturalizmowi.

Naturalizm milcząco przeczy przekonaniu, że stworzenie jest odrębne od swego Stwórcy. Logiczne jest zatem, że naturaliści chcieli odpowiedzieć na wielkie pytania o początki bez odniesienia do Stwórcy. Nowy reżim intelektualny (naturalizm) opanowywał kulturę, mimo iż większość nie zdawała sobie sprawy, czym on naprawdę jest. Nie miał nic wspólnego z klerykalizmem, nie budowano w jego imię świątyń, nie tworzono symboli czy przeznaczonych tylko dla niego miejsc kultu. Nic zatem dziwnego, że w ramach naturalizmu odpowiedzi na pytania o pochodzenie odwołują się do nowego bóstwa - do prawa przyrody.

Nie zważając na naturalistyczne spekulacje, zawodowi biolodzy i członkowie szeroko rozumianej kultury nadal byli przekonani, że życie zawdzięcza swe istnienie na Ziemi wielkiemu inteligentnemu projektantowi. Dla większości współczesnych czytelników nie od razu oczywiste jest, jak właściwie dziewiętnastowieczni biolodzy wnioskowali o działaniu przyczyny inteligentnej. Z lektury wielu książek sprzed 1859 roku, poświęconych problematyce biologicznej, jeśli nie zna się kodu słownego, niełatwo domyślić się, że zawarta w nich argumentacja przemawia na rzecz inteligentnego projektu. Tymczasem dla przeddarwinowskich biologów możliwość stwierdzenia, że dany organizm jest zaadaptowany do swojego środowiska lub jakaś struktura przystosowana do pełnienia swojej funkcji, była równoznaczna $\mathrm{z}$ wykazaniem, że zostały one celowo zaprojektowane, a więc że są wytworem inteligentnej istoty. 
Zanim Karol Darwin ogłosił swoją teorię, wszyscy sądzili, że projekt wymaga projektanta. Koncepcja inteligentnego projektu zniknęła jednak z biologii wraz z triumfem Darwina, który utrzymywał, że dobór naturalny tworzy w organizmach tylko złudzenie projektu.

\section{Dowody laboratoryjne}

Dlaczego naukowcy nie uważają już, że w przyrodzie przejawia się inteligentny projekt? Można odpowiedzieć krótko, że naturalistyczna kultura potrzebuje naturalistycznego wyjaśnienia, zaś naukowcy potrafią wskazać wiele przykładów naturalnych procesów tworzących uporządkowane wzorce. Zarówno piękne wzorce widoczne w kryształach, w mydlanych wirach powstających przy otworach odpływowych, jak też porządek obserwowany $w$ galaktykach spiralnych dowodzą, że zwykłe siły fizyczne $\mathrm{z}$ łatwością tworzą uporządkowanie.

Oto świetny „kuchenny” przykład zdolności przyczyn naturalnych do tworzenia uporządkowania. Jeśli na kuchence z możliwością precyzyjnej regulacji ciepła powoli będziemy podgrzewać wypełniony olejem, okrągły, szklany pojemnik o płaskim denku, to po chwili na powierzchni oleju spontanicznie pojawią się sześciokątne wzorce. Uogólniając wynik tego doświadczenia, można stwierdzić, że powstanie uporządkowania wymaga jedynie, aby zachodził przepływ energii przez układ fizyczny.

Nauka głosi, że nawet jeśli cały Wszechświat potraktujemy jako system termodynamicznie izolowany, czyli taki, w którym energia w końcu się wyczerpie, to i tak istnieją w nim regiony, w których dzięki przepływowi energii stan uporządkowania może utrzymywać się długo. Już sama ta wiedza wystarczyła, aby materialiści mogli obronić się przed klasycznym argumentem, że ,uporządkowanie oznacza projekt, a projekt — projektanta". A ponieważ większości dzisiejszych naukowców argument $\mathrm{z}$ projektu nie przekonuje, wielu wykształconych ludzi idzie ich śladem i także go odrzuca. 
Przez tysiąc dziewięćset lat historii Zachodu panował pogląd, że istnienie uporządkowania da się wyjaśnić jedynie celowym działaniem inteligentnej istoty. Dominujący pogląd minionego jej stulecia głosi natomiast, że nie trzeba już odwoływać się do przyczyny inteligentnej. Naukowcy dowiedli, że procesy naturalne tłumaczą wiele przykładów uporządkowania w świecie, i zakłada się, że każdy rodzaj uporządkowania uzyska podobne wyjaśnienie.

\section{Uporządkowanie, złożoność i informacja}

Nagle wydarzyło się coś nieoczekiwanego. Kiedy się już wydawało, że przyczyny naturalne mogą wyjaśnić wszystkie zjawiska przyrodnicze, w matematyce i biologii dokonano przełomowych odkryć, które umożliwiają radykalną zmianę sposobu opisywania organizmów żywych i wyjaśniania ich pochodzenia.

Zacznijmy od biologii. Większość współczesnych ludzi słyszała o kwasie deoksyrybonukleinowym — DNA, podwójnie spiralnej cząsteczce dziedziczności. Przypomina on spiralną drabinę. Ramiona tej drabiny zbudowane są z cukru i cząsteczek fosforanu. Jej „szczeble” tworzą zaś cztery zasady: adenina (A), guanina (G), cytozyna (C) i tymina (T). Nukleotyd składa się z zasady połączonej z cukrem, do którego przyłączony jest fosforan. Polinukleotyd to długi ciąg połączonych ze sobą nukleotydów (połączenia utworzone są z fosforanu i cukru), niczym samochody przewożone na długim pociągu.

Podczas replikacji wewnątrz komórki obie strony „drabiny” rozłączają się i każda połowa przyciąga $\mathrm{z}$ otaczającego płynu nowy zestaw nukleotydów, który zastępuje brakującą drugą jej połowę. Sekwencja nukleotydów tworzących nowy łańcuch DNA liczy od kilku milionów (u bakterii) do trzech miliardów (u człowieka). Ważna jest nie tylko długość łańcucha, ale także swoista kolejność nukleotydów.

DNA nazywany jest cząsteczką informacyjną, ponieważ jego unikalna struktura działa jak centralny element zawiłego wewnątrzkomórkowego systemu komunikacyjnego. Na to, że DNA pełni rolę kodu, 
uwagę zwrócili Francis Crick i James Watson, ogłaszając odkrycie podwójnej helisy DNA. Wcześniej Crick napisał o tym w liście do swojego syna Michaela, datowanym na 19 marca 1953 roku: „Obecnie uważamy, że DNA jest kodem. Oznacza to, że kolejność zasad (liter) odróżnia jeden gen od drugiego (tak jak jedna strona wydrukowanego tekstu różni się od drugiej)".

Drugą grupą informacyjnych cząsteczek są białka, czyli długie, przypominające łańcuch cząsteczki, zbudowane z połączonych ze sobą aminokwasów, które zwijają się, tworząc bardzo skomplikowane kształty. Specyficzna kolejność aminokwasów w białku determinuje zarówno jego ogólny, trójwymiarowy kształt, jak i funkcję.

Czterozasadowy alfabet DNA i alfabet białkowy, na który składa się dwadzieścia aminokwasów, stanowią podstawę dwóch różnych języków powiązanych ze sobą kodem. Kiedy komórka buduje białka, jeden język tłumaczony jest na drugi. Kolejność zasad w DNA koduje i określa kolejność aminokwasów w białku.

Teoria informacji to gałąź matematyki, w ramach której opracowano metodę pomiaru informacji. Krótko mówiąc, zawartość informacji w danej strukturze to minimalna liczba instrukcji potrzebnych do jej opisania albo specyfikacji (zawartość informacyjną można mierzyć w przypadku dowolnej struktury: skały, statku kosmicznego, sterty liści czy nawet żywego organizmu). Im bardziej złożona struktura, tym więcej instrukcji wymaga jej opis.

\section{Uporządkowanie: periodyczne i wyspecyfikowane}

Rozwój teorii informacji umożliwił rozróżnienie pomiędzy uporządkowaniem a złożonością. Przykładami struktur uporządkowanych są powtarzające się wzory na tapecie lub panelach podłogowych, sześciokątne wzory pojawiające się na powierzchni podgrzewanego oleju, jedna struktura powielona wielokrotnie w krysztale oraz ciąg liter alfabetu ABABABABAB... Charakterystyczną cechą struktury uporządkowanej jest PERIODYCZNE i WYSPECYFIKOWANE ułożenie jej 
części składowych. Oznacza to, że części ułożone są w wysoce powtarzalny i specyficzny sposób. Takie struktury mają niską zawartość informacyjną, a ich specyfikacja wymaga tylko kilku instrukcji.

Gdybyśmy na przykład chcieli powiedzieć chemikowi, jak utworzyć kryształ, potrzebowalibyśmy tylko dwóch instrukcji: (1) wybierz odpowiedni związek i sposób ułożenia cząsteczek oraz (2) powiedz chemikowi: „teraz zrób to jeszcze raz” i powtarzaj tę czynność, dopóki nie powstanie kryształ. Informację o strukturze kryształu wystarczy podać raz, ponieważ ma ona regularny wzór.

Wydanie komputerowi polecenia, by zapełnił stronę wielokrotnie powtarzającym się zdaniem „Witaj Bob!”, również wymagałoby jedynie dwóch instrukcji: (1) „drukuj «W-i-t-a-j B-o-b-!»” i (2) ,zrób to jeszcze raz", dopóki nie zapełni się strona.

\section{Zlożoność: aperiodyczna i niewyspecyfikowana}

Struktury aperiodyczne, to jest takie, które nie są periodyczne, nazywane są „,złożonymi”. Są dwa typy struktur złożonych. Najprostszy typ złożoności to struktura losowa. Nie jest ona uporządkowana, ale - tak jak struktura charakteryzująca się uporządkowaniem - zawiera niewiele informacji, ponieważ jej specyfikacja wymaga niewielu instrukcji. Struktury losowe są z definicji APERIODYCZNE i NIEWYSPECYFIKOWANE, podobnie jak grudka granitu, sterta liści bądź losowo utworzony polimer lub ciąg liter.

Sterta liści jest strukturą losową i do jej wyspecyfikowania wystarczą już dwie instrukcje: (1) „wybierz dowolny typ liścia i rzuć na stertę" i (2) „zrób to jeszcze raz”. Utworzenie losowego ciągu liter także wymaga tylko dwóch instrukcji: (1) ,wybierz losowo literę od A do Z i zapisz ją" oraz (2) „zrób to jeszcze raz”. W ten sposób można utworzyć dowolnie długi losowy ciąg liter. 


\section{Informacja: aperiodyczna i wyspecyfikowana}

Dla biologii większe znaczenie ma drugi typ złożoności. Wiadomości pisane, artefakty, DNA i białka to przykłady wyspecyfikowanej złożoności. Struktury charakteryzujące się wyspecyfikowaną złożonością to te, których części składowe mają układ aperiodyczny i wyspecyfikowany. Takie struktury mają dużą zawartość informacyjną, co znaczy, że ich specyfikacja wymaga wielu instrukcji.

Aby utworzyć kopię Mowy Gettysburskiej Lincolna, która zaczyna się słowami: „Przed osiemdziesięcioma siedmioma laty...”, nie wystarczy wprowadzić do komputera małego zbioru instrukcji. Instrukcje będą miały dokładnie taką długość, jak cały tekst tej słynnej mowy. Należy określić każdą literę, jedną po drugiej i to w poprawnej kolejności. Nie istnieje droga na skróty.

Zaopatrzenie chemika w zbiór kilku instrukcji, jak zsyntetyzować DNA nawet najprostszej bakterii, również byłoby praktycznie niemożliwe. Instrukcje musiałyby dotyczyć każdej kolejnej chemicznej litery. Byłoby ich zatem kilka milionów. Instrukcje nie ograniczyłyby się do kilku zdań — mogłaby z nich powstać całkiem spora książka.

Dysponujemy zatem precyzyjnym, matematycznym rozróżnieniem pomiędzy uporządkowaniem a złożonością. Doświadczenie wskazuje, że procesy naturalne tworzą uporządkowane struktury, takie jak faliste wzory na piaszczystej plaży, sześciokątne wzorce na powierzchni podgrzewanego oleju i kryształy. $Z$ doświadczenia wiemy również, że procesy naturalne potrafią utworzyć losowy rozkład opadających jesienią liści oraz losowe polimery, czego dowodzą wyniki eksperymentów odnoszących się do pochodzenia życia.

Doświadczenie podsuwa nam też wiele przykładów wyspecyfikowanej złożoności, której źródłem jest inteligencja (książki, obrazy, artefakty), ale w żadnym razie nie wskazuje, by wyspecyfikowaną złożoność mogły wytworzyć procesy naturalne. Cechą charakterystyczną organizmów żywych nie jest uporządkowanie, lecz wyspecyfikowana 
złożoność, czyli informacja. To zdumiewające odkrycie ma oczywiście doniosłe konsekwencje dla argumentu z projektu.

\section{Nowy argument z projektu}

Filozofowie i teologowie od dawien dawna utrzymywali, że uporządkowanie wymaga inteligencji, a tę nazywano Bogiem. Dzięki zastosowaniu metody wnioskowania abdukcyjnego od skutków wstecz wiemy już, iż procesy naturalne mogą tworzyć uporządkowanie, a zatem inteligencja nie jest $\mathrm{w}$ tym wypadku potrzebna (chyba że mamy na myśli pogląd - utrzymywany zresztą przez wielu teistów - że inteligencja odpowiada za procesy naturalne). Jednak wraz z odkryciem cząsteczek informacyjnych — DNA i białek — które nie charakteryzują się uporządkowaniem, lecz wyspecyfikowaną złożonością, sytuacja uległa diametralnej zmianie.

DNA, białka oraz rzecz jasna istoty żywe są bogate w informację. Inne struktury, które cechuje wyspecyfikowana złożoność, to: wiadomości pisane, mosty, obrazy, programy komputerowe i inne ludzkie artefakty.

Naukowcy odkryli, że genetyczne wiadomości zapisane w DNA są pod względem strukturalnym identyczne $\mathrm{z}$ pisanymi wiadomościami ludzkiego języka. Otworzyło to drogę dla zastosowania teorii informacji w biologii. Teoria informacji stosuje się do każdego systemu symboli, bez względu na charakter jego elementów. Tzw. Shannonowskie prawa informacji obowiązują jednakowo w ludzkim języku, kodzie Morse'a oraz kodzie genetycznym. W artykule opublikowanym na łamach Journal of Theoretical Biology Hubert P. Yockey zauważył:

Należy mieć świadomość, że nie rozumujemy tu przez analogię. Hipoteza sekwencji [mówiąca, że dokładna kolejność symboli jest zapisem informacji] stosuje się bezpośrednio zarówno do białek i tekstu genetycznego, jak i do języka pisanego. Dlatego też ich ujęcia matematyczne niczym się od siebie nie różnią. ${ }^{6}$

\footnotetext{
${ }^{6}$ Hubert P. YockeY, „Self Organization Origin of Life Scenarios and Information Theory", Journal Theoretical Biology 1981, vol. 91, no. 1, s. 16 [13-31].
} 
Cząsteczki DNA (i białka) mają identyczną strukturę jak wiadomości pisane. Ponieważ jedyną znaną z doświadczenia przyczyną wiadomości pisanych jest inteligencja, zastosowanie metody abdukcyjnej implikuje, że DNA i białka powstały za sprawą inteligentnej przyczyny. Waga tego wniosku kryje się w stopniu jego pewności, gdyż jest on znacznie większy niż gdyby struktury te były do siebie tylko podobne. Nie chodzi tu o żadne powierzchowne podobieństwo pomiędzy DNA a wiadomościami pisanymi. Nie twierdzimy, że DNA jest jak wiadomość, a raczej, że DNA jest wiadomością. W taki oto sposób do biologii powraca pojęcie prawdziwego projektu.

\section{Odpowiedzi na najczęstsze zarzuty}

Jeśli zastosujemy abdukcyjną metodę wnioskowania bezpośrednio do genetycznego tekstu, nasunie się wniosek, że DNA miał inteligentną przyczynę. Jednakże niewielu naukowców ten wniosek akceptuje. Jaki jest tego powód? Dlaczego naukowcy i spora część przedstawicieli szerzej rozumianej kultury akurat $\mathrm{w}$ tym jednym przypadku DNA (i białek) - nie przestrzegają abdukcyjnej metody wnioskowania? Zdążyliśmy się już przekonać, że program poszukiwania inteligencji pozaziemskiej oraz ogólna metodologia medycyny sądowej uznawane są za naukowe, a zatem ani nauka, ani kultura nie są z samej zasady przeciwne powoływaniu się na przyczyny inteligentne.

Źródła tego sprzeciwu należy więc szukać gdzie indziej, w czymś, co rozpowszechniło się w kulturze i przenika ją na wskroś. Gdyby to źródło tkwiło wyłącznie w nauce, to idei projektu nie sprzeciwiano by się również $\mathrm{w}$ obrębie ogólnie rozumianej kultury lub na gruncie dowolnej gałęzi nauki, w której nie prowadzi się badań nad DNA.

Podstawą kulturowej opozycji wobec koncepcji głoszącej, że DNA miał inteligentną przyczynę, są trzy główne zarzuty: filozoficzny, metodologiczny i psychologiczny. Dlaczego zatem naukowcy i spora część przedstawicieli szerzej rozumianej kultury akurat w tym jednym przypadku — DNA (i białek) — nie przestrzegają abdukcyjnej metody wnioskowania? 


\section{Zarzut filozoficzny}

Pierwszy zarzut przeciwko hipotezie inteligentnego projektu DNA ma charakter filozoficzny. Większość naukowców, zwłaszcza tych, którzy zajmują się problemem pochodzenia życia, wyrobiła już w sobie nawyk dzielenia zjawisk na naturalne i nadnaturalne. Dlatego też naukowcy łatwo przyjmują, że pojęcie inteligentnej przyczyny to podstęp, a w rzeczywistości chodzi o przyczynę nadnaturalną, tyle że zwolennicy nadnaturalizmu nie mają odwagi tego przyznać. A ponieważ sfera nadnaturalna nie wchodzi w zakres nauki, to zjawiska przyrodnicze badać można jedynie przy założeniu, że ich przyczyna jest naturalna.

Nietrudno zrozumieć, dlaczego krytyk może sądzić, że mówienie o inteligentnej przyczynie to podstęp - przyczyna taka rzeczywiście może mieć charakter nadnaturalny. Problem w tym, że wnioskowanie na podstawie DNA (i białek) nie pozwala jednoznacznie stwierdzić, czy postulowana inteligencja pochodzi z wewnątrz kosmosu, czy spoza niego. Określenia „z wewnątrz” i „spoza” pełnią tu kluczową rolę: ponieważ na mocy samego wnioskowania nie da się wskazać, które z tych określeń trafnie odzwierciedla rzeczywistość, nie możemy wyeliminować tej dwuznaczności. To właśnie dlatego musimy mówić po prostu o inteligentnej przyczynie.

Ten filozoficzny zarzut czerpie siłę z pomieszania kategorii i terminów naukowych z filozoficznymi. Naukowcy posługują się empirycznie ugruntowanymi terminami „,naturalny” i ,,inteligentny”. Omówiony wcześniej przypadek wykrywania inteligibilnych sygnałów z kosmosu to przykład naukowego zastosowania terminu ,przyczyna inteligentna”. Kiedy jednak dyskusja dotyczy inteligentnej przyczyny znajdującej się na zewnątrz czy poza kosmosem, używa się już filozoficznego terminu „nadnaturalny”, który wskazuje, że chodzi o coś transcendentnego, czyli wykraczającego poza doświadczenie.

Ponadto, kiedy naukowcy wnioskują o przyczynie falistych wzorów na piaszczystej plaży, posługują się opartym na doświadczeniu 
terminem „przyczyna naturalna”. Kiedy jednak dyskusja wokół przyczyny naturalnej wykracza na zewnątrz czy poza sferę doświadczenia, w obszary fillozoficzne, nie używa się innego filozoficznego terminu. Stosuje się natomiast pewien wariant słowa „naturalny” — naturalizm. Terminu „naturalny” używa się często bez wyraźnego wskazania, że przechodzi się od sfery naukowej do filozoficznej, a dwuznaczność tego słowa prowadzi do niemałego zamieszania. Powód tego zamieszania najłatwiej dostrzec dzięki zestawieniu obok siebie dwóch dychotomicznych podziałów, w których ten termin się pojawia:

Nauka
naturalny/inteligentny

\section{Filozofia}

naturalny/nadnaturalny

Nie można wymyślić czegoś bardziej zwodniczego. Wystarczy tylko zacząć dyskusję, mówiąc o nauce i stosownie używając terminu „,naturalny”, i gdzieś po drodze zwyczajnie przejść na grunt filozofii, również tym razem używając terminu „naturalny” w stosowny na tym gruncie sposób, zapominając jedynie o powiadomieniu słuchaczy lub czytelników, że przeszło się do kwestii filozoficznych. Za pomocą takiego triku rzeczywiście łatwo można „przekonać” swoich odbiorców.

Nietrudno dostrzec, że takie zamieszanie może powstać nawet wtedy, gdy nikt nie chce świadomie zwodzić innych, nieuchronnie bowiem prowadzi do tego użycie określonych zwrotów językowych.

Rozważmy na przykład poniższe cytaty. Pierwszy to słowa fizyka Paula Daviesa, a drugi — Lesliego Orgela, wybitnego badacza pochodzenia życia:

Powstanie życia pozostaje jedną z wielkich tajemnic naukowych. [...] Problemem jest zrozumienie, w jaki sposób zwykłe procesy fizyczne i chemiczne mogły doprowadzić do osiągnięcia tego progu bez interwencji jakiegoś czynnika nadprzyrodzonego. ${ }^{7}$

\footnotetext{
${ }^{7}$ Paul Davies, Bóg i nowa fizyka, przeł. Piotr Amsterdamski, Wydawnictwo Cyklady, Warszawa 1996, s. 91.
} 
Każdy „żywy” system musi być rezultatem albo długiego procesu ewolucji, albo cudu. ${ }^{8}$

Obaj autorzy chcieli, aby ich słowa były zrozumiałe w kontekście nauki, i poszukiwali naukowego rozwiązania zagadki pochodzenia życia. Obaj pomieszali jednak kategorie naukowe z filozoficznymi. Właściwym naukowym terminem na oznaczenie alternatywy dla fizycznych i chemicznych procesów (Davies) oraz procesu ewolucji (Orgel) jest przyczyna inteligentna, nie zaś czynnik nadprzyrodzony (Davies) albo cud (Orgel).

Mieszanie kategorii utrudnia oczywiście sensowną komunikację. Cytaty tego typu stawiają czytelnika przed fałszywym wyborem pomiędzy nauką a filozofią. Cokolwiek autorzy mieli na myśli, zamierzonym bądź niezamierzonym skutkiem takich wypowiedzi jest zasugerowanie czytelnikowi, że nauka (a może raczej naturalizm?) stanowi jedyny akceptowalny wybór.

Podsumowując, u podstaw filozoficznego zarzutu wobec koncepcji, że DNA miał inteligentną przyczynę, leży założenie, iż owa przyczyna ma charakter nadnaturalny. Zwykle towarzyszy temu mieszanie kategorii i terminów naukowych z filozoficznymi. W nauce właściwą, bazującą na doświadczeniu alternatywą dla naturalnej przyczyny jest przyczyna inteligentna.

\section{Zarzut metodologiczny}

Drugi zarzut wobec twierdzenia o inteligentnej przyczynie DNA jest metodologiczny. Zgodnie z nim nauka ogranicza się do poszukiwania przyczyn naturalnych. Nieważne przy tym, czy czyimś filozoficznym światopoglądem jest naturalizm czy teizm. Inteligentna przyczyna jest w nauce nie do przyjęcia, ponieważ ma charakter metafizyczny. To podejście niektórzy jego zwolennicy nazwali naturalizmem metodologicznym.

\footnotetext{
${ }^{8}$ Leslie Orgel, The Origins of Life, John Wiley, New York 1973, s. 192.
} 
Za tym zarzutem kryje się wzniosła idea, mianowicie promowanie nauki i wykluczanie $z$ niej tych filozoficznych i religijnych poglądów, które naukę tylko udają. Naturalizm metodologiczny nie jest jednak prawdziwą naukową zasadą, każe bowiem dopasować się do przyjętego z góry wyobrażenia nauki, porzucając właściwą metodę, jaką jest podążanie za tym, co mówi doświadczenie.

Naturalizm metodologiczny ma krótką historię. Zaczyna się ona w dziewiętnastym wieku, kiedy to zwolennicy naturalizmu naukowego upierali się, że nauka musi mówić wyłącznie o przyczynach naturalnych. Dzisiaj niektórym może się wydawać, że naturalizm metodologiczny miał niewinne początki. Ignorując znaczenie kulturowego zwrotu od teizmu do naturalizmu, powiązanego z zainteresowaniem kwestią pochodzenia, łatwo wyobrazić sobie, że naukowcy na przestrzeni około czterystu lat kierowali się prawidłową metodą wnioskowania o przyczynach na podstawie doświadczenia i systematycznie, w każdym przypadku docierali do przyczyn naturalnych. Metoda nakazująca podążać za doświadczeniem tak nieomylnie wiodła dotychczas do przyczyn naturalnych, że niektórzy mogą sądzić, iż nauka musi ograniczać się do poszukiwania takich właśnie przyczyn.

Niemniej naturalizm metodologiczny jest błędny, ponieważ ignoruje zasadę kierowania się doświadczeniem. Przykład cząsteczek informacyjnych doskonale ilustruje, że nakłada on arbitralne ograniczenie na przyrodę i jest bezzasadnym wymogiem metodologii naukowej. To właśnie sprawia, że naturalizm metodologiczny jest ewidentnie sprzeczny z duchem nauki.

Wielu ludzi, którzy nie prowadzą badań nad DNA, wciąż nie uświadamia sobie znaczenia tych informacyjnych cząsteczek i nie wie, że w świetle metody abdukcyjnej ich najbardziej prawdopodobną przyczyną jest inteligencja. Wniosek ten jest nie do przyjęcia na gruncie naturalizmu metodologicznego, który z góry określa, że przyczyna musi być naturalna. Gdyby jednak naturalizm metodologiczny stosowano konsekwentnie, to badacze z NASA musieliby poszukiwać naturalnych przyczyn dla wszystkich inteligibilnych sygnałów wychwyty- 
wanych z przestrzeni kosmicznej. Należałoby wówczas uznać również, że każda struktura cechująca się wyspecyfikowaną złożonością i znaleziona na którejkolwiek z planet musi mieć przyczynę naturalną.

Jeśli nie ma żadnych uzasadnionych metodologicznych podstaw dla zakwestionowania hipotezy, że DNA miał inteligentną przyczynę (a uważam, że takimi podstawami rzeczywiście nie dysponujemy), to co należy sądzić o jej przeciwnikach? Metafizyczni naturaliści pozostaną w opozycji, dopóki nie znajdą sposobu na wkomponowanie tego rezultatu badań nad DNA w swój metafizyczny punkt widzenia. W międzyczasie wciąż będą kwestionować hipotezę inteligentnej przyczyny, ale coraz trudniej im będzie posługiwać się starym argumentem, że pogląd, w myśl którego należy rozpatrywać wyłącznie przyczyny naturalne, to „po prostu nauka”. Dla przedstawicieli szerzej rozumianej kultury stanie się natomiast jasne, że pod szyldem nauki metafizyczni naturaliści przez wiele lat przemycali do kultury metafizyczny naturalizm.

Co jednak z metafizycznymi teistami, zwłaszcza tymi, którzy są przeciwni powoływaniu się $\mathrm{w}$ nauce na przyczyny inteligentne jedynie z powodów metodologicznych? Można żywić nadzieję, że gdy tylko zrozumieją, iż naturalizm metodologiczny to naprawdę jedynie arbitralne ograniczenie narzucone przyrodzie, a także bezzasadny wymóg metodologiczny, otwarcie o tym powiedzą i pomogą rozpowszechnić tę istotną wiedzę. Należy tak robić, dopóki bowiem naturalizmu metodologicznego nie uda się uzasadnić na jakimś nowym gruncie, będzie on nieodróżnialny od naturalizmu metafizycznego.

\section{Zarzut psychologiczny}

Trzeci zarzut wobec hipotezy inteligentnego zaprojektowania DNA jest psychologiczny. Duża część chrześcijańskich naukowców, w tym zwolennicy naturalizmu metodologicznego, jest psychologicznie uprzedzona do przekonania, że w nauce można rozważać cokolwiek innego niż przyczyny naturalne. Ma to związek z faktem, że w przeszłości chrześcijanie przyjmujący podejście zwane „Bogiem luk 
w poznaniu świata" (God of the gaps), to jest przywołujący Boga ad hoc, by wypełnić jakąś lukę w ludzkiej wiedzy, niejednokrotnie doznawali upokorzenia, widząc, że Bóg jest stopniowo z nauki usuwany. Uczeni wiele zagadkowych zjawisk przyrodniczych wyjaśnili przecież działaniem przyczyn naturalnych. Była to bolesna lekcja dla Kościoła, a dziś stała się ona psychologicznym podłożem sprzeciwu wielu chrześcijan (reprezentujących zarówno środowiska naukowe, jak też szersze kręgi kultury) wobec koncepcji inteligentnej przyczyny, gdyż boją się oni powtórki tego smutnego — trzeba przyznać — rozdziału historii Kościoła.

Nie ma jednak podstaw, by się spodziewać, że jakieś przyszłe naukowe odkrycie naturalnej przyczyny informacyjnych sekwencji DNA obali wnioskowanie o projekcie tej cząsteczki. Odkrycie, że naturalne przyczyny potrafią tworzyć wyspecyfikowaną złożoność, oznaczałoby znacznie więcej niż tylko „kolejne rozczarowanie”. W wątpliwość mogłaby zostać poddana cała uznana wiedza o przeszłości. Zagrożona byłaby na przykład nasza wiedza o antyku, opierająca się na założeniu, że rozszyfrowaliśmy antyczne języki, którą zdobywamy przecież jedynie przy założeniu trafności metody przyczynowego wnioskowania na podstawie doświadczenia, a zastosowanie tej metody prowadzi do wniosku, że najprawdopodobniejszą przyczyną starożytnych artefaktów i zapisków w nieznanym języku jest inteligencja. Nie można byłoby ufać nawet znalezionemu na strychu aktowi urodzenia, który identyfikowałby kogoś jako prawomocnego spadkobiercę majątku rodzinnego.

\section{Zakończenie}

Abdukcyjna metoda wnioskowania o przyczynach na podstawie doświadczenia to uznana metoda naukowa. Jest ona otwarta zarówno na przyczyny naturalne, jak też inteligentne. Klasycznym przykładem wnioskowania abdukcyjnego jest opowiadanie o detektywie szukającym wskazówek mogących pomóc rozwiązać tajemnicę czyjejś śmierci. Pojęcie inteligentnej przyczyny oraz pojęcie projektu zniknęły 
z nauk przyrodniczych po ogłoszeniu teorii Darwina, chociaż wciąż powoływano się na nie w niektórych innych gałęziach nauki. Dzięki przełomowym odkryciom w dziedzinie matematyki i biologii, których dokonywano począwszy od 1950 roku, dowiedzieliśmy się, że w sercu procesów życiowych znajduje się cząsteczka DNA, której cechą charakterystyczną nie jest uporządkowanie, lecz wyspecyfikowana złożoność, czyli informacja.

Struktura DNA i wiadomości pisane są identyczne pod względem matematycznym. Ta strukturalna identyczność oraz fakt, że inteligencja jest jedyną znaną przyczyną wyspecyfikowanej złożoności, to znaczy informacji, pozwalają na sformułowanie nowego i mocniejszego argumentu z projektu.

Jestem w pełni świadom, że większość ludzi jest dziś przekonana, iż pewien naturalny proces przyczynowy thumaczy powstanie i rozwój ziemskiego życia oraz że według wielu teistów proces ten został zaprojektowany przez Boga. W mniemaniu takich osób jest to oczywisty fakt. Jeżeli jednak nie dysponujemy bezpośrednimi świadectwami, to każdy taki scenariusz musi opierać się wyłącznie na poszlakach. Mimo że często można w ten sposób dojść do trafnych wniosków, warto przytoczyć słowa szacownego detektywa, Sherlocka Holmesa, na temat innej trudnej zagadki:

— Poszlaki mogą być mylące — stwierdził Holmes z zamyśleniem. — Może się wydawać, że wyraźnie na coś wskazują, a jeśli nieco zmienisz punkt widzenia, okazuje się, że równie niewątpliwie świadczą o czymś całkiem innym. [...] Nie ma nic bardziej złudnego niż oczywisty fakt! ${ }^{9}$

Charles Thaxton

\footnotetext{
${ }^{9}$ Arthur Conan Doyle, Przygody Sherlocka Holmesa, przeł. Marta Domagalska, w: Arthur Conan Doyle, Księga wszystkich dokonań Sherlocka Holmesa, wyd. 2, Wydawnictwo REA, Warszawa 2011, s. 205 [163-318].
} 